\title{
Реализация продовольственной политики Временного правительства на территории Забайкалья
}

\author{
Н.В. Тумурхонова
}

Бурятская государственная сельскохозяйственная академия им. В.Р. Филиппова (Улан-Удэ, Россия)

\section{The Realization of Food Policy of the Provisional Government in the Territory of the Trans-Baikal Region}

\author{
N.V. Tumurkhonova \\ V.R. Filippov Buryat State Agricultural Academy (Ulan-Ude, Russia)
}

Рассмотрена реализация политики Временного правительства по решению продовольственного вопроса на территории Забайкальской области. Автором введены в научный оборот документы, характеризующие организацию продовольственного дела в 1917 г. и деятельность продовольственных органов в Забайкалье.

С приходом к власти Временное правительство реорганизовало систему управления продовольственным делом: в стране повсеместно были созданы губернские, уездные районные волостные продовольственные комитеты, а в Забайкальской области в районах компактного проживания коренного бурятского населения дополнительно аймачные, хошунные, сомонные продовольственные комитеты. Главные мероприятия Временного правительства по преодолению продовольственного кризиса - введение хлебной монополии, установление твердых закупочных цен на сельскохозяйственную продукцию, реквизиция скота и мяса были направлены на налаживание прямого товарообмена между городом и деревней. В Забайкалье данные меры оказались малоэффективны, так как область относилась к потребляющим регионам, а в условиях неурожая хлебов и трав 1917 г. не могла удовлетворить потребности собственного населения в продовольствии.

Ключевые слова: продовольственный вопрос, Временное правительство, Забайкальская область, хлебная монополия, реквизиция скота.

\section{DOI 10.14258/izvasu(2019)5-08}

Первая мировая война стала серьезным испытанием для экономики Российской империи, хозяйству которой был нанесен серьезный ущерб. В начале войны в правящих кругах присутствовало устойчивое
The article considers the realization of the Provisional Government policy on the food issue in the TransBaikal region. The author introduced the documents describing the organization of food business in 1917 and the activities of food authorities of Trans-Baikal region into the scientific circulation.

Coming to authority, the Provisional Government reorganized the food management systems. The provincial, county, district, parish, food committees were created all over the country, and in the Trans-Baikal region, in areas densely populated by the indigenous Buryats, aymachny, hoshunny, somonnyy food committees were established additionally. The main Provisional Government measures to overcome the food crisis were the introduction of the grain monopoly, establishing solid purchase prices for agricultural products, livestock and meat requisition were aimed to establish a direct exchange of goods between town and country.

In the Trans-Baikal region, those measures turned out to be ineffective since the region belonged to consumed regions, but under the conditions of grain and herb crop failure in 1917, could not satisfy needs of its own population for food.

Key words: food issue, Provisional Government, TransBaikal Region, grain monopoly, livestock requisition.

мнение о невозможности продовольственного кризиса, так как Россия являлась одним из основных поставщиков сельскохозяйственной продукции в мире. Предполагалось, что в связи с прекращением продо- 
вольственного экспорта цены на сельскохозяйственную продукцию понизятся.

В ходе войны были нарушены традиционные экономические связи, транспортная инфраструктура, что затруднило товарообмен между отдельными регионами. Мобилизация привела к дефициту рабочей силы в деревне. В результате оккупации была выведена из хозяйственного оборота часть плодородных земель, сократилось производство хлеба. В это же время спрос на сельскохозяйственную продукцию вырос.

Первые проблемы с поставкой продовольствия появились в 1915 г., к началу 1917 г. ситуация стала критической. Продовольственный кризис стал одним из катализаторов революционного взрыва февраля 1917 г. Придя к власти, Временное правительство вынуждено было принять меры по его преодолению.

В последнее десятилетие в отечественной историографии опубликован ряд исследований, рассматривающих продовольственное положение в стране после Февральской революции. В работах А.Н. Федорова, М.В. Оськина, А.П. Канайкина, И.В. Сахневич проанализирована политика Временного правительства по преодолению продовольственного кризиca, дана характеристика мероприятиям по заготовке продовольствия органами государственной власти. Авторы отмечают, что от решения данного вопроса зависело существование демократической власти [1-4]. В трудах О.Н. Кузнецовой, О.П. Королькова, С.И. Мунжуковой, Н.В. Липатовой дана оценка деятельности продовольственных органов и особенностей реализации продовольственной политики на местах [5-8]. А.Ю. Давыдов уделил внимание проблемам массового участия гражданского населения в «теневой» экономике, появлению таких явлений, как «мешочничество» и «солдатская кооперация», причины которых он видит в противоречивой и разнонаправленной экономической политике новой власти [9].

В рамках данного исследования особый интерес представляют публикации М.В. Оськина, В.В. Синиченко, О.А. Устюговой, в которых затронуты вопросы заготовки продовольствия в Забайкальской области, проанализированы внешнеторговые связи России с Китаем и Монголией, рассмотрена деятельность «Монголэкса» [10-13]. Следует отметить, что продовольственная политика Временного правительства в Забайкальской области в современной отечественной историографии не выступала самостоятельным предметом изучения.

С приходом к власти Временного правительства для разработки общегосударственного продовольственного плана 9 марта 1917 г. был создан Общегосударственный продовольственный комитет под председательством министра земледелия
А.И. Шингарева, на местах организованы местные продовольственные комитеты (продкомы) [14, с. 24].

В Забайкалье были созданы районные продкомы в Чите, Троицкосавске, Верхнеудинске, Петровском-Заводе, Баргузине, Селенгинске, Акше, Александровском заводе, Нерчинске, Стретенске, Агинском и на станциях Оловянная и Борзя с подчинением Забайкальскому областному продкому под председательством А.М. Ярмоша. Волостные, станичные, поселковые продкомы находились под управлением районных комитетов. Дополнительно по инициативе Бурятского национального комитета (Бурнацкома) в мае-июне в районах компактного проживания бурятского населения были образованы Агинский, Хоринский, Селенгинский и Баргузинский аймачные продкомы $[15$, л. 2, 15, 53]. Продкомы осуществляли общее руководство продовольственным делом, контролировали цены, вели учет хлеба и предметов первой необходимости; отвечали за организацию реквизиций продовольствия, определение условий поставок хлеба государству, организацию снабжения населения, проведение статистического учета и пр. [16, c. 15-17]. В состав продовольственных органов вошли представители земских собраний, городов, Советов рабочих депутатов, Крестьянского союза, кооперативов, сельскохозяйственных обществ, статистических, агрономических и санитарно-медицинских организаций, представители торгово-промышленного класса, крестьяне, частные землевладельцы. Численный состав продовольственных комитетов определялся в соответствии с Положением о местных продовольственных органах [16, с. 9-14].

Для обеспечения населения и армии хлебом 25 марта 1917 г. Временное правительство приняло постановление «О передаче хлеба в распоряжение государства», согласно которому весь хлеб урожая 1916 и 1917 гг, за вычетом запаса, необходимого для продовольствия и хозяйственных нужд, переходил в ведение государства. Доставка в ссыпные пункты возлагалась на владельцев хлеба. В случае выявления скрытых запасов хлеб подвергался отчуждению по сниженной на 50\% цене. У лиц, отказывающихся от добровольной сдачи хлеба, хлеб реквизировался. Принудительному отчуждению подлежали все наличные запасы хлеба, в том числе и хранящиеся в сельских общественных хлебозапасных магазинах [16, с. 1-8].

С введением хлебной монополии правительство предполагало ограничить торговлю хлебом частными лицами и установить прямой товарообмен между городом и деревней под контролем государства путем введения норм их потребления и создания системы распределения.

$86,6 \%$ населения области проживало в сельской местности и было занято аграрным производством, однако полностью Забайкалье хлебом было обе- 
спечено только в урожайные годы. Среднегодовые потребности в привозном хлебе, по данным текущей статистики Забайкальской области, за период с 1909 по 1913 г. составляли 2,8 млн пудов [15, л. 29]. Хлеб ввозился из Предбайкалья, Западной Сибири, Приамурья и Маньчжурии.

Урожай 1916 г. был относительно хорошим, однако стратегических запасов хлеба в регионе не было. Весной-летом 1917 г. хлеб доставляли в режиме текущей заготовки. В августе-сентябре в связи с началом уборочной страды, нехваткой рабочих рук (в армию из области было мобилизовано 43\% трудоспособного мужского населения), плохим прогнозом на урожай доставка хлеба крестьянами практически прекратилась [17, с. 22]. На запросы продкомов крестьяне отвечали: «Окончим уборку, повезем хлеб» $[18$, л. 10, 17].

В 1917 г. урожай в области оказался ниже среднего примерно на 20\%, с окончанием уборочной поставки хлеба не увеличились [17, с. 11]. В сентябре Батуринской, Верхне-Талецкой и прочим волостям требовалось до 60 тыс. пудов муки, Верхнеудинску 50 тыс. пудов, а «возможно было поставить» лишь 15 тыс. пудов [18, л. 7об., 13]. По данным Забайкальского областного продкома, в 1917 г. область нуждалось в дополнительных 3820 тыс. пудах зерна [18, л. 39об].

В августе с целью активизации продажи хлеба крестьянством правительство утвердило новые твердые закупочные цены, повысив их в два раза [15, л. 80-81] (табл.).

Предельные закупочные цены на зерно и муку в Забайкальской области (руб. за пуд)

\begin{tabular}{|l|c|c|c|}
\hline \multicolumn{1}{|c|}{ Зерно и мука } & $\begin{array}{c}\text { Закупаемые } \\
\text { у производителей }\end{array}$ & $\begin{array}{c}\text { Принимаемые } \\
\text { из хлебозапасных магазинов }\end{array}$ & $\begin{array}{c}\text { Отчуждаемые у частных } \\
\text { торговцев, скупщиков }\end{array}$ \\
\hline Ярица & 2,35 & 2,10 & 2,10 \\
\hline Овес / Ячмень & 2,20 & 1,90 & 1,90 \\
\hline Пшеница & 3,35 & 3 & 3 \\
\hline Мука ржаная & 2,70 & 2,70 & 2,70 \\
\hline Мука пшеничная & 3,70 & 3,70 & 3,70 \\
\hline
\end{tabular}

Введение твердых закупочных цен в Забайкалье не достигло намеченных целей, так как они не соответствовали ценам на черном рынке. Крестьяне негативно отнеслись к реализации хлебной монополии, отказывались сдавать хлеб государству, предпочитая реализовывать его на черном рынке по более высокой цене. Рост рыночных цен с сентября до конца октября составил примерно 50\%, к ноябрю цена на пшеницу составляла 6 руб. за пуд, ржаную муку - 5 руб. за пуд [19, л. 1]. В это же время спекулянты развернули агитацию против передачи хлеба государству. Нелегальные скупщики, отправлявшие хлеб в Монголию, предлагали за пуд на 1 руб. больше «русских цен».

Ввоз хлеба из соседних регионов Сибири был невозможен, поставки хлеба из Маньчжурии были ограничены. По сообщениям областного продкома, в августе-октябре из Маньчжурии для всего Забайкалья можно было поставить только 225 вагонов хлеба в месяц (225 тыс. пудов). При заказе китайского хлеба необходимо было внести задаток 25\% от его стоимости, но расстройство финансовой системы страны и нехватка денежных средств лишали продкомы и кооперативы возможности оплачивать большие партии китайского хлеба [15, л. 29].

Запасы хлеба, хранящиеся в хлебозапасных магазинах, также не могли покрыть потребности области в хлебе. По данным текущей статистики в предвоенные годы в магазинах Забайкалья хранилось до 500 тыс. пудов хлеба. Процесс ликвидации хле- бозапасных магазинов, предусмотренный введением хлебной монополии, затягивался. К сентябрю магазины были ликвидированы лишь частично и сохранились практически на всей территории области [20, л. 12; 21, л. 1-4; 22]. В начале октября 1917 г. Забайкальский продком попытался активизировать работу по передаче хлеба в распоряжение государства. Перед волостными и станичными продкомами была поставлена задача - провести учет хлеба и организовать доставку излишков в ближайшие ссыпные пункты.

Крестьянство выступило против изъятия хлеба из хлебозапасных магазинов. В продовольственные органы массово стали поступать ходатайства от крестьян с просьбами об исключении их магазинов из «учета государства», так как хлеб, хранящийся в них, из-за неурожая планируется передать нуждающимся [22, л. 4, 7]. Завершить начатую работу продовольственным органам на территории области не удалось.

Помимо земледелия, население Забайкалья занималось кочевым скотоводством. По количеству скота на душу населения область занимала одну из ведущих позиций в Сибири. В годы войны Забайкалье стало одним из основных регионов - поставщиков скота (лошадей), мяса, кожи для нужд армии. Для организации поставок мяса царским правительством была создана Монгольская экспедиция, в Сибирь были направлены специальные уполномоченные - П.К. Козлов, В.Г. Гей и А.А. Дудукалов 
[23, л. 50]. Экспедицией в 1915, 1916 гг. из Забайкалья было вывезено около 200 тыс. пудов мяса [24, с. 8]. Неоднократно в области производились реквизиции лошадей для нужд армии.

После Февральской революции деятельность специальных уполномоченных продолжилась. Для упорядочивания закупок Забайкальский облпродком ввел твердые закупочные цены на мясо - 10-12 руб. за пуд «за вычетом 15\% на расходы по организации поставки скота» [23, л. 50-51]. Закупка мяса у населения осуществлялась через кооперативы.

Уполномоченный Прибайкальского товарищества кооперативов В.Г. Юрасов отмечал, что ему удалось закупить в Баргузинском аймаке только 2 тыс. пудов мяса, «ввиду нежелания населения продавать его по низкой фиксированной цене», в это же время «спекулянтам удалось закупить около 10 тыс. пудов» по более высокой цене [23, л. 170].

По инициативе представителей кооперативов был введен запрет на покупку скота у бурятского населения посторонними лицами и выгона уже закупленного скота за пределы области, весь скот, закупленный посторонними лицами, брали под контроль до выяснения его назначения [23, л. 52].

1 сентября 1917 г. Министерство продовольствия Временного правительства опубликовало циркуляр о реквизиции скота для нужд государства на территории Забайкалья. Реквизиция должна была осуществляться с 1 октября 1917 г. по 1 июля 1918 г. Реквизиции подлежали $1 / 6$ часть поголовья волов и быков, 1/10 часть - поголовья коров и весь «сверхремонтный молодняк в возрасте от полутора до двух с половиной лет». Желающие могли заменить поставку живого скота на мясо [25, л. 115]. В счет разверстки принимался скот, закупленный агентами и обществами потребителей Прибайкальского товарищества кооперативов или Монгольской экспедицией.

Вся тяжесть разверстки ложилась на бурятское хозяйство. Возможности заготовки мяса и реквизиции скота в традиционно скотоводческих Агинском и Баргузинском аймаках к осени 1917 г. осложнялись неблагоприятными природно-климатическими условиями - засухой и уничтожением травяного покрова кобылкой. Население Баргузинского аймака не смогло заготовить сено, неурожай трав усугублялся отсутствием его запасов. Во избежание серьезных последствий бескормицы население аймака массово перекочевывало в пределы Баргузинской тайги, на Витим и Амалат или в пределы Хоринского аймака. В августе-сентябре около 25 тыс. голов крупного рогатого скота и несколько тысяч голов овец были выгнаны на Витим, выгон этого скота обратно по глубокому снегу в район Баргузина, где располагался приемный пункт, был невозможен. Скот, который находился в пределах аймака, был истощен, а реквизиция его осложнялась необходимостью доставки за счет владельцев, из Баргузина до ближайшей железнодорожной станции Татаурово 300-450 верст. Из-за неурожая трав резко выросли цены на сено, вдоль Баргузинского тракта продажи сена прекратились [23, л. 115]. Доставка мяса на станцию Татаурово была невозможна из-за высоких цен на перевозку (4 руб. 50 коп. за пуд, при закупочной цене от 10 руб. за пуд), отсутствия желающих заняться извозом вследствие призыва в армию извозчиков-профессионалов и реквизиции лошадей [26, л. $24 ; 23$, л. 160].

В Агинском и Хоринском аймаках реквизиции подлежало 20563 и 24523 голов крупного рогатого скота, ее проведение осложнялось отсутствием точных сведений о количестве скота. Агинскому аймачному продкому не удалось получить сведения о поголовье по Хамниганскому и Онгоцонскому хошунам. Часть домохозяйств Агинского и Хоринского аймаков кочевали в пределах Монголии около 1000 и 200 хозяйств соответственно [20, л. 56; 27, л. 30]. Местные аймачные продкомы выступили с ходатайством перед Забайкальским областным продовольственным комитетом об отсрочке реквизиции до лета 1918 г. [23, л. 115]. Крестьянское население области также отказывалось от поставок скота по реквизиции, ссылаясь «на неимение излишнего скота» [26, л. 2, 3, 6].

Политика Временного правительства по налаживанию прямого товарообмена между городом и деревней в Забайкалье не имела положительных результатов, так как была рассчитана на производящие губернии, которые в обмен на поставку хлеба через продовольственные органы должны были получить предметы первой необходимости. Забайкальская область традиционно относилась к потребляющим регионам.

В итоге в области был введен запрет на вывоз хлеба и всякого рода хлебных продуктов, фуража и скота, мяса, мясных продуктов, сала, кожи, хлопчатобумажных тканей и мешков, сахара, табака, махорки, масла, сена и мыла. Лица, виновные в нарушении запрета, подвергались уголовному преследованию $[15$, л. 78,101$]$. Для предотвращения бесконтрольного вывоза в ряде населенных пунктов были установлены караулы, вводились запреты на продажу продовольствия частным лицам [26, л. 2].

Для налаживания снабжения населения на местах были установлены месячные нормы потребления продовольствия и товаров первой необходимости: 35 ф. ржаной муки, 5 ф. крупы (любой), 3 ф. соли, 1 ф. сахара, 1 ф. мяса, 4 ф. чая, 2 аршина ситца в месяц на одного человека $[18$, л. 1$]$.

Таким образом, несмотря на все меры, предпринятые Временным правительством для стабилизации продовольственного положения в Забайкальской области, ситуация продолжала ухудшаться, возможности крестьянского и инородческого хозяйства были 
истощены. Политика Временного правительства не имела поддержки у населения области, которое отказывалось поставлять продовольствие по низким закупочным ценам.

В июле 1917 г. в городских населенных пунктах области была введена карточная система на продовольственные товары и товары первой необходимости.
Введение карточной системы в Забайкалье повсеместно планировалось в октябре 1917 г. Сельское население негативно отнеслось к решению о введении карточной системы. Развернуть карточную систему в Забайкалье не удалось, в октябре 1917 г. Временное правительство было свергнуто в ходе Октябрьской революции.

\section{Библиографический список}

1. Федоров А.Н. Организация продовольственного дела в революционной России (март-октябрь 1917 г.) // Известия вузов. Поволжский регион. Гуманитарные науки. 2010. №2.

2. Оськин М.В. Продовольственный вопрос в России в 1917 году: слабое место новой власти // Научные ведомости Белгородского государственного университета. Серия: История. Политология. 2015. №7 (204).

3. Канайкин П.А. Продовольственный вопрос в России в сентябре-октябре 1917 года // Сервис в России и за рубежом. 2013. №2.

4. Сахневич И.В. Правовые основы продовольственной политики Временного правительства // Юридические записки. 2014. №1.

5. Кузнецова О.Н. Деятельность Комиссии для обследования положения продовольственного дела в Петрограде в 1917 г. // НИР. 2017. №4 (21). URL: https: http:// modernhistory.ru/d/1607380/d/kuznetsova_0.pdf (дата обращения: 15.02.2019).

6. Корольков О.П. Продовольственный вопрос в Псковской губернии в 1917 г. и Великая российская революция // Псков. Научно-практический, историко-краеведческий журнал. 2011. №34. URL: https:// http://izd. pskgu.ru/projects/pgu/storage/PSKOV/ps34/ps_34_10.pdf (дата обращения: 8.02.2019).

7. Мунжукова С.И. Проблема распределения продовольствия и карточная система Петрограда в 1917 г. // Петербургский исторический журнал. 2018. №3 (19).

8. Липатова Н.В. Ошибка регионального масштаба. Хлебная монополия Временного правительства и ее последствия // Центр и периферия. 2015. № 4. URL: http://73history.ru/doc/publikacii/ LipatovaHlebMonopolia WtynhGthta4-2015.pdf (дата обращения: 17.02.2019).

9. Давыдов А.Ю. Легальный и нелегальный рынки в России 1917 года: взаимодействие и роль в революционном процессе // Общественные науки и современность. 2018. №2.
10. Оськин М.В. Заготовки продовольствия в Восточной Сибири и на Дальнем Востоке в период Первой мировой войны // Россия и АТР. 2016. №2 (92).

11. Оськин М.В. Монголия - России: организация «Монголэкс» до и после революции 1917 г. // Россия и АТР. 2018. №3 (101).

12. Синиченко В.В. Влияние курса рубля на деятельность по закупке продовольствия для нужд армии и тыла в годы Первой мировой войны // Иркутский историкоэкономический ежегодник. Иркутск, 2017.

13. Устюгова О.А. Дальний Восток России в системе внешнеторговых связей накануне и во время революций 1917 г. // Россия и АТР. 2017. №3 (97).

14. Сборник указов и постановлений Временного правительства. Вып. 1. 27 февраля - 5 мая 1917 г. Пг., 1917.

15. Государственный архив Республики Бурятия (ГАРБ). Ф.Р. 244. Оп.1. Д. 6.

16. Действия правительства. Постановление Временного правительства. О передаче хлеба в распоряжение государства и о местных продовольственных органах. Чита, 1917.

17. Текущая статистика. Урожай хлебов и трав в Забайкальской области в 1917 г. (По сообщениям добровольных корреспондентов Статистического отдела). Чита, 1918.

18. ГАРБ. Ф.Р. 244. Оп 1. Д. 5.

19. ГАРБ. Ф.Р. 307. Оп. 1. Д. 2.

20. ГАРБ. Ф.Р. 905. Оп 1. Д. 18.

21. ГАРБ. Ф.Р. 905. Оп. 1. Д. 4.

22. ГАРБ. Ф.Р. 1652. ОП. 1. Д. 3.

23. ГАРБ. Ф.Р. 244. Оп 1. Д. 1.

24. Долидович О.М. Изменение условий функционирования мясного потребительского рынка в Иркутском генерал-губернаторстве в годы Первой мировой войны // Проблемы социально-экономического развития Сибири. 2018. №2 (32).

25. ГАРБ. Ф.Р. 244. Оп 1. Д. 7.

26. ГАРБ. Ф.Р. 1652. Оп. 1. Д. 4.

27. ГАРБ. Ф.Р. 905. Оп. 1. Д. 16. 